\title{
SISTEM INFORMASI GEOGRAFIS PEMETAAN \\ JENIS POTENSI RAWAN BENCANA ALAM DI \\ WILAYAH DAERAH ALIRAN SUNGAI (DAS) \\ KABUPATEN BEKASI
}

\begin{abstract}
Dwipa Handayani, Hendarman Lubis
Jurusan Teknik Informatika, Fakultas Teknik, Universitas Bhayangkara Jakarta Raya3

E-mail :dwipa.handayani@dsn.ubharajaya.ac.id,hendarman.lubis@dsn.ubharajaya.ac.id
\end{abstract}

Abstrak

Memberikan pengetahuan informasi tentang apa itu bencana dan bagaimana cara menanggulanginya, serta membantu masyarakat dalam mengetahui potensi kerawanan bencana di daerahnya masing-masing.Metode sistem informasi pendukung keputusan menggunakan metode Rapid Application Development (RAD). Hasilnya menunjukan suatu sistem yang dapat memenuhi harapan dari user merupakan tujuan utama dari semua metode pengembangan.

Kata Kunci: Sistem Informasi Geografis, Rapid Application Development (RAD).

Abstract

Provide information about what is disaster and how to overcome it, and assist the community in knowing potential disaster vulnerability in their respective areas. Method of supporting information system using Rapid Application Development (RAD) method. The result is a user-usable system.

Keywords: Geographic Information System, Rapid Application Development (RAD).

\section{PENDAHULUAN}

Daerah Aliran Sungai (DAS) merupakan istilah yang merujuk pada suatu kawasan dimana air hujan mengalir menuju penampungan air seperti kali, sungai, danau, dan rawa-rawa. Penampungan air tersebut pada akhirnya akan menyalurkan air ke tempat yang lebih rendah hingga mencapai laut. Daerah ini umumnya dibatasi oleh batas topografi merupakan tempat tertinggi (punggung bukit) sehingga air hujan yang jatuh didalamnya akan selalu menuju tempat hilirnya (bagian yang lebih rendah).

Daerah Aliran Sungai berfungsi sebagai penampung air hujan, daerah resapan, daerah penyimpanan air, penangkap air hujan dan pengaliran air. Wilayahnya meliputi bagian hulu bagian hilir, bagian pesisir dan dapat berupa wilayah lindung, wilayah budidaya, wilayah pemukiman dan lain-lain.. Kerusakan DAS dipercepat oleh peningkatan pemanfaatan sumberdaya alam sebagai akibat dari pertambahan penduduk dan perkembangan ekonomi, konflik kepentingan dan kurang keterpaduan antar sektor, terutama pada era otonomi daerah.

Kasus disini penulis melakukan objek penelitian diwilayah kabupaten bekasi yaitu sungai kali Bekasi, Kali Bekasi memiliki dimensi panjang keseluruhan sebesar \pm 11 kilo meter dan kedalaman bervariasi antara 5-11 meter dan lebar 
10-25 meter. Kali Bekasi Menurut warga setempat yang tinggal didaerah aliran sungai kenaikan volume air biasa terjadi apabila musim hujan dalam waktu lama begitu juga dengan genangan air yang ada di beberapa jalan rusak

Kali Bekasi merupakan daerah pengairan sungai yang cukup luas. Lingkungan yang berada disepanjang kali bekasi merupakan daerah pemukiman sebagai akibat dari perkembangan daerah yang saar ini berfungsi sebagai daerah penyangga ibu kota jakarta.

\section{TINJAUAN PUSTAKA}

Penulis melakukan penelitian pada wilayah sekitaran daerah aliran sungai di kabupaten bekasi tepatnya di Kecamatan Babelan Desa Bunibakti dan Desa Muarabakti sebagai tempat penyebaran kuisioner dimana desa tersebut adalah salah satu desa yang di lalui oleh sungai kali bekasi sebagai objek pada peneitian ini.

Perangkat pendukung penelitian ini adalah membuat kuisioner dan wawancara terhadap masyarakat yang tinggal di wilayah aliran sungai dengan pemasalahan yang sedang penulis teliti. Menjelaskan apa itu bencana alam, titik titik tempat berpotensi bencana alam yang akan di tampilkan dalam sistem informasi tesebut.

Melakukan uji coba tehadap aplikasi yang dibuat, metode yang digunakan adalah pembuatan sistem informasi geografis pemetaan jenis potensi rawan bencana alam diwilayah daerah aliran sungai(DAS) Kabupaten Bekasi ini adalah metode RAD (Rapid Application Development).

\section{METODELOGI PENELITIAN}

Di zaman sekarang teknologi menjadi hal yang dimanfaatkan semua orang baik berbisnis atau mencari informasi, mudahnya mendapatkan informasi dari berbagai macam elektronik dan juga sumbernya. Maka dari itu untuk kasus ini penulis membuat sistem informasi bagi masyarakat yang awam tentang informasi potensi bencana alam sistem informasi ini di khususkan untuk masyarakat yang tinggal di daerah rawan bencana alam di tempat tinggalnya, seperti informasi potensi bencana, Informasi solusi yang dilaku kan ketika menghadapi bencana, hingga informasi bentuk kesiapsiagaan masyarakat menghadapi bencana alam tersebut.

1. Usecase Diagram

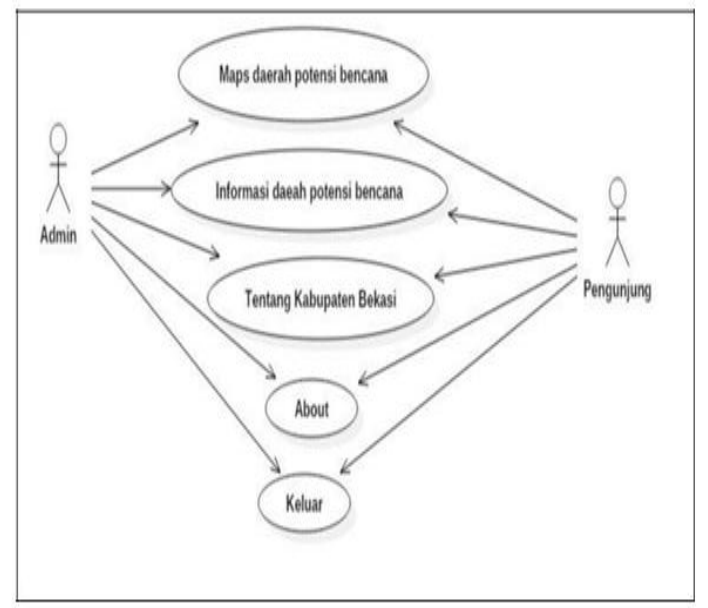

Gambar4.1 Use Case Diagram

2. Sequence Diagram

a. Sequence Diagram Menu Maps

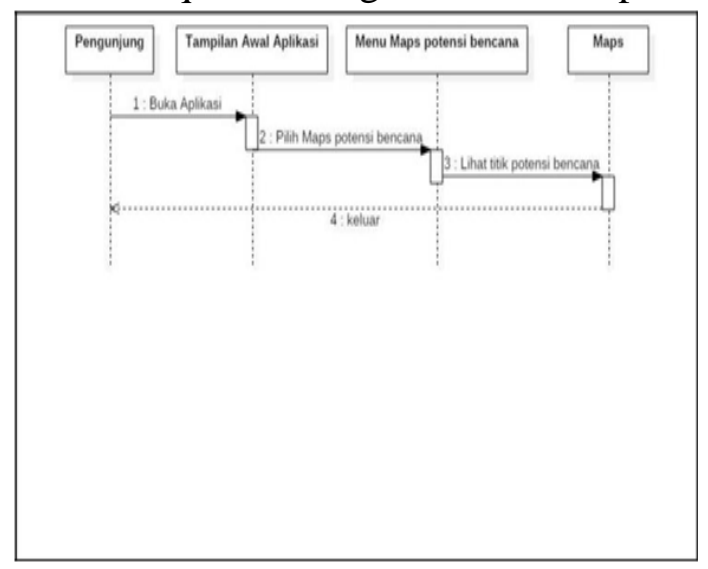

Gambar4.2 Sequence Diagram 
Gambar 4.2 menggambarkan tentang Sequance diagram maps daerah yang berpotensi bencana alam di DAS, pengunjung dapat melihat titik atau lokasi desa yang memiliki riwayat potensi bencana alam di Kabupaten Bekasi.

b. Sequence Diagram Menu Informasi

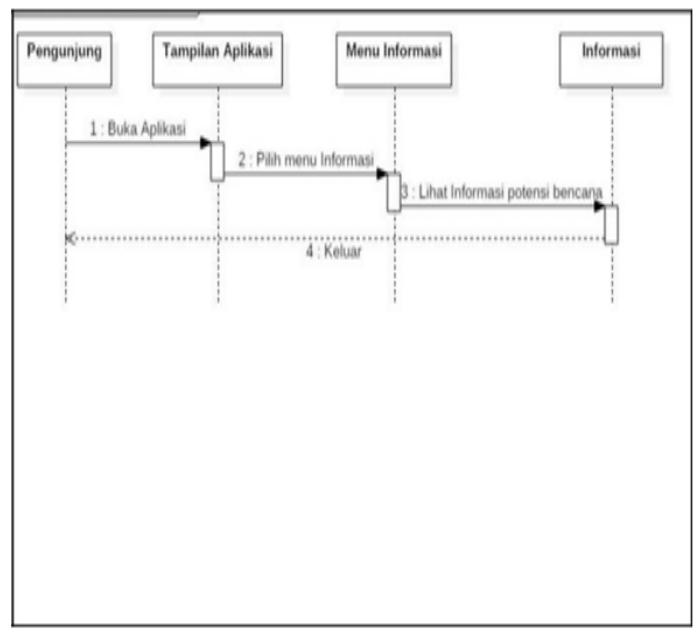

Gambar 4.3 Sequence Diagram

Gambar 4.3 Menggambarkan tentang Sequance diagram Informasi daerah yang berpotensi bencana alam di DAS, pengunjung dapat melihat informasi berupa daerah yang berpotensi, volume air, serta informasi saran yang dapat dilihat didalam aplikasi.

c. Sequence Diagram Menu Tentang Kabupaten

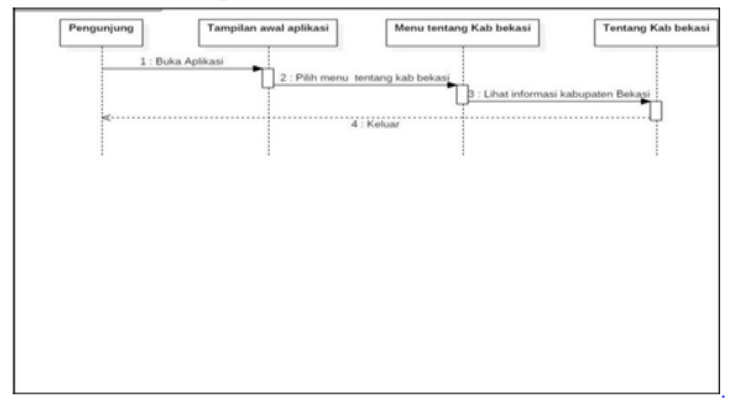

Gambar 4.4 Sequence Diagram

Gambar 4.4 Menggambarkan sequance diagram tentang Kabupaten bekasi, Pengunjung dapat melihat informasi
Kabupaten bekasi, letak Topografi Kabupaten Bekasi.

d. Sequence Diagram Menu

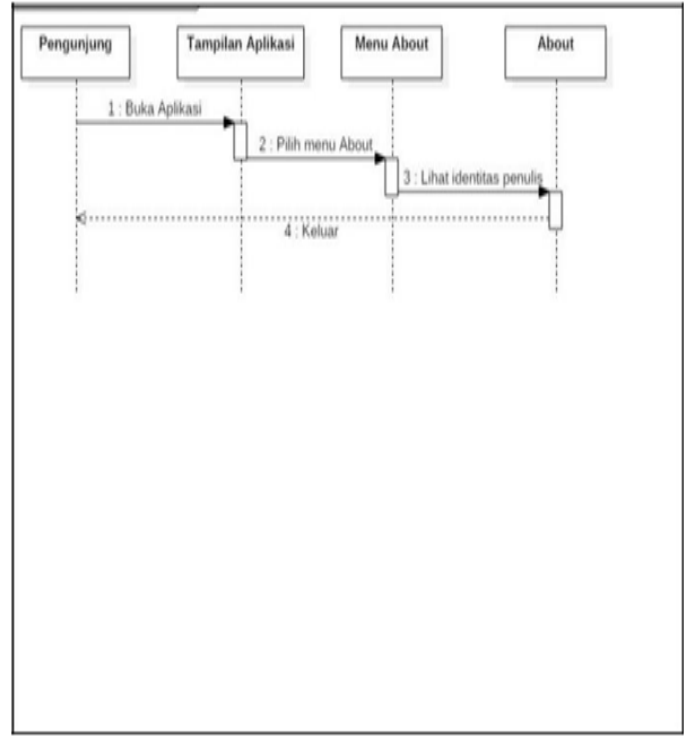

Gambar 4.5 Sequence Diagram

Gambar 4.5 Menggambarkan

Sequance diagram menu About, dimana menu tersebut berisi informasi berupa biodata penulis.

e. Sequence Diagram Menu Keluar

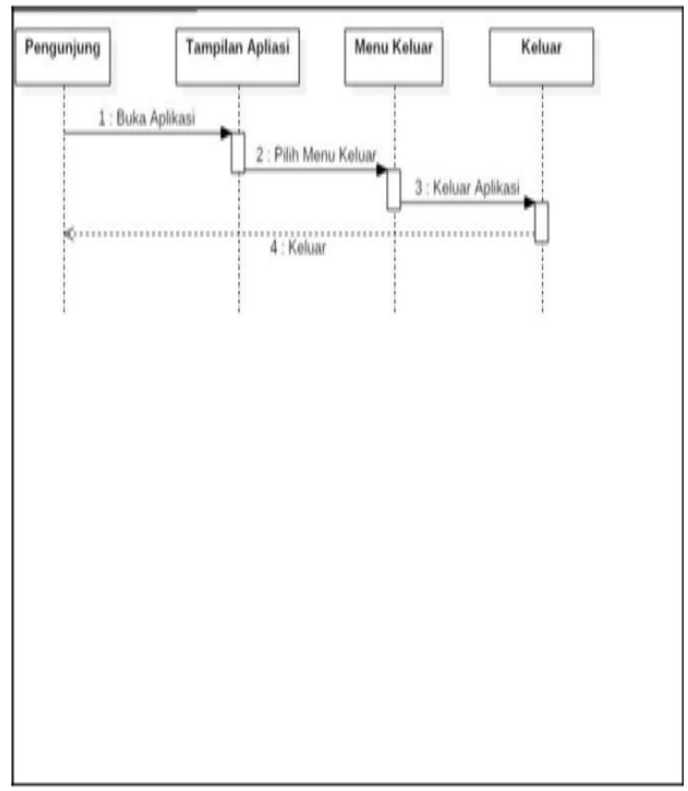

Gambar 4.6 Sequence Diagram

Gambar 4.6 Menggambarkan sequance diagram menu keluar, dimana 
pengunjung dapat melihat suatu pertanyaan apakah ingin keluar dari aplikais atau tidak jika tidak kembali ke tampilan awal aplikasi dan jika ya pilih keluar pada aplikasi.

\section{Activity Diagram}

a. Activity Diagram Menu Maps daerah berpotensi bencana alam diwilayah aliran sungai

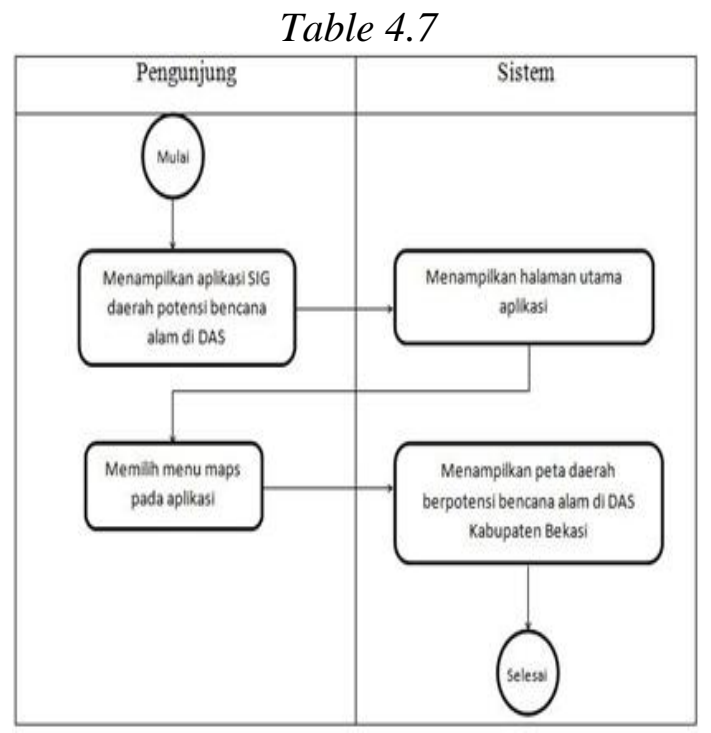

Tabel 4.7 menggambarkan tentang activity diagram maps daerah yang berpotensi bencana alam di DAS, pengunjung dapat melihat tampilan berupa titik-titik manasaja yang berpotensi bencana alam dengan penyajian informasi sesuai letak geografisnya.

b. Activity Diagram Menu Informasi daerah berpotensi bencana alam diwilayah aliran sungai
Table 4.8

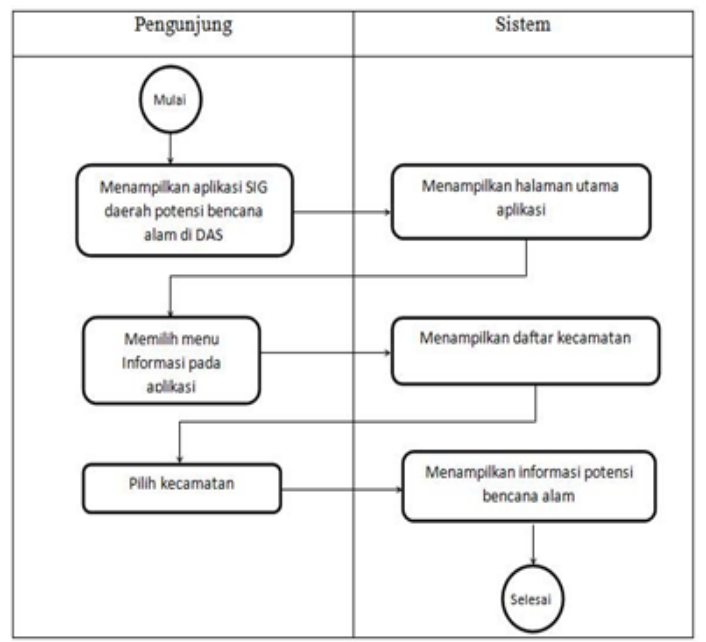

Tabel 4.8 menggambarkan tentang actvity diagram maps daerah yang berpotensi bencana alam di DAS, pengunjung dapat melihat informasi berupa daerah manasaja yang berpotensi bencana alam, volume air, serta informasi saran yang dapat dilihat didalam aplikasi.

\section{c. Activity Diagram Menu Kabupaten Bekasi}

Table 4.9

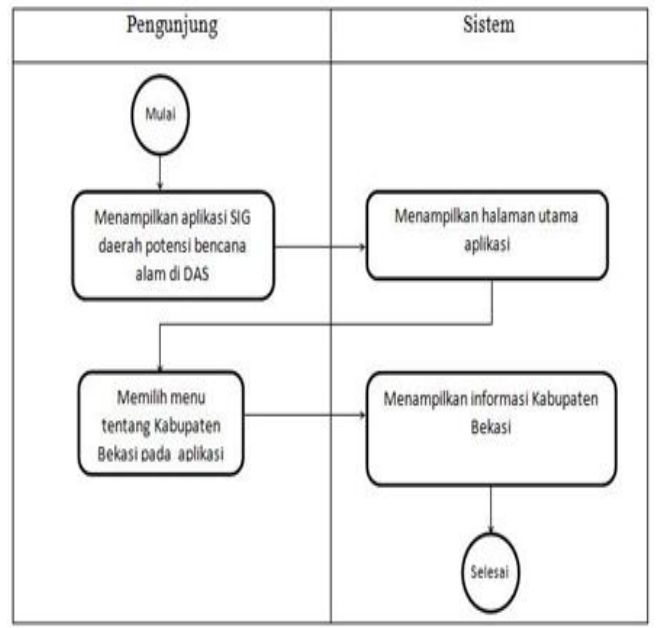

Tabel 4.9 menggambarkan activity diagram tentang Kabupaten Bekasi. Pengunjung dapat melihat informasi Kabupaten Bekasi, topografi Kabupaten Bekasi. 
d. Activity Diagram Menu About

Table 4.10

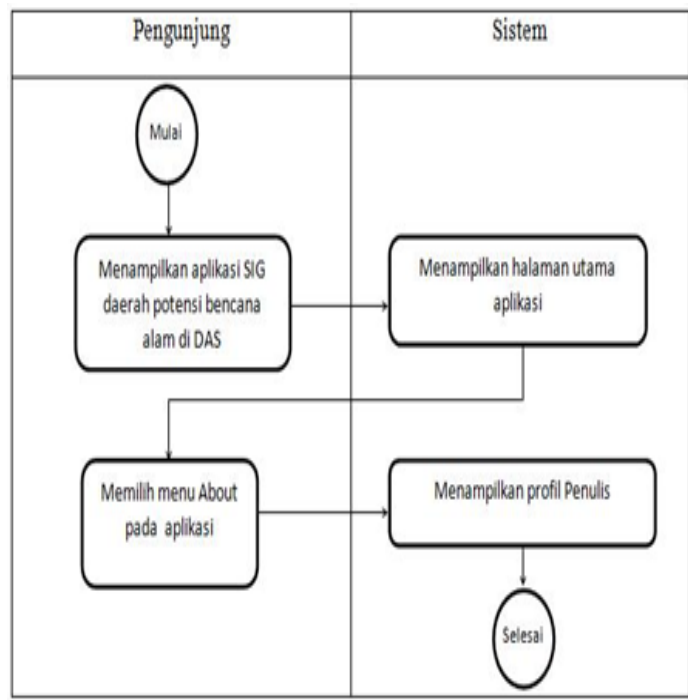

Tabel 4.10 menggambarkan tentang activity diagram menu about, pengunjug dapat melihat informasi penulis berupa biodata penulis, asal universitas, program studi dan foto penulis.

e. Activity Diagram Menu Keluar

\section{Table 4.1.1}

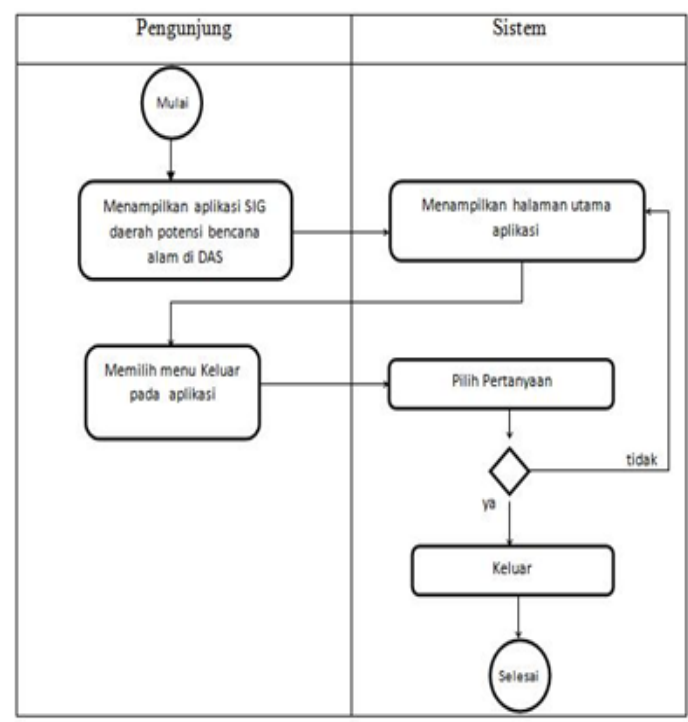

Tabel 4.1.1 menggambarkan tentang activity diagram menu keluar. Pengunjung dapat melihat pertanyaan keluar pada aplikasi jika keluar pilih exit dan jika tidak bisa kembali ke tampilan utama aplikasi.

\section{Metode Pengembangan Sistem}

Pada penelitian ini, Penulis menggunakan metode pengembangan sistem Rapid Application Development (RAD) karena RAD mempunyai kemampuan untuk menggunakan komponen yang sudah ada dan waktu yang lebih singkat maka membuat biaya menjadi lebih rendah. Berikut adalah proses pemodelan RAD dalam pembuatan aplikasi ini :

\section{a. Pemodelan Bisnis}

Tahap pemodelan bisnis adalah teknik pemodelan fungsi bisnis untuk mengetahui informasi apa saja yang terkait dengan proses bisnis, siapa yang harus membuat informasi itu, bagaimana alur informasi itu dan proses apa saja yang terkait informasi tersebut.

\section{b. Analisa Sistem Berjalan}

Analisa sistem berjalan adalah gambaran dari sistem yang saat ini sedang berjalan dari suatu komponen dengan maksud untuk mengidentifikasi bentuk permasalahan yang sedang terjadi. 
Table Flowmap sistem berjalan potensi bencana alam di daerah aliran sungai (DAS)

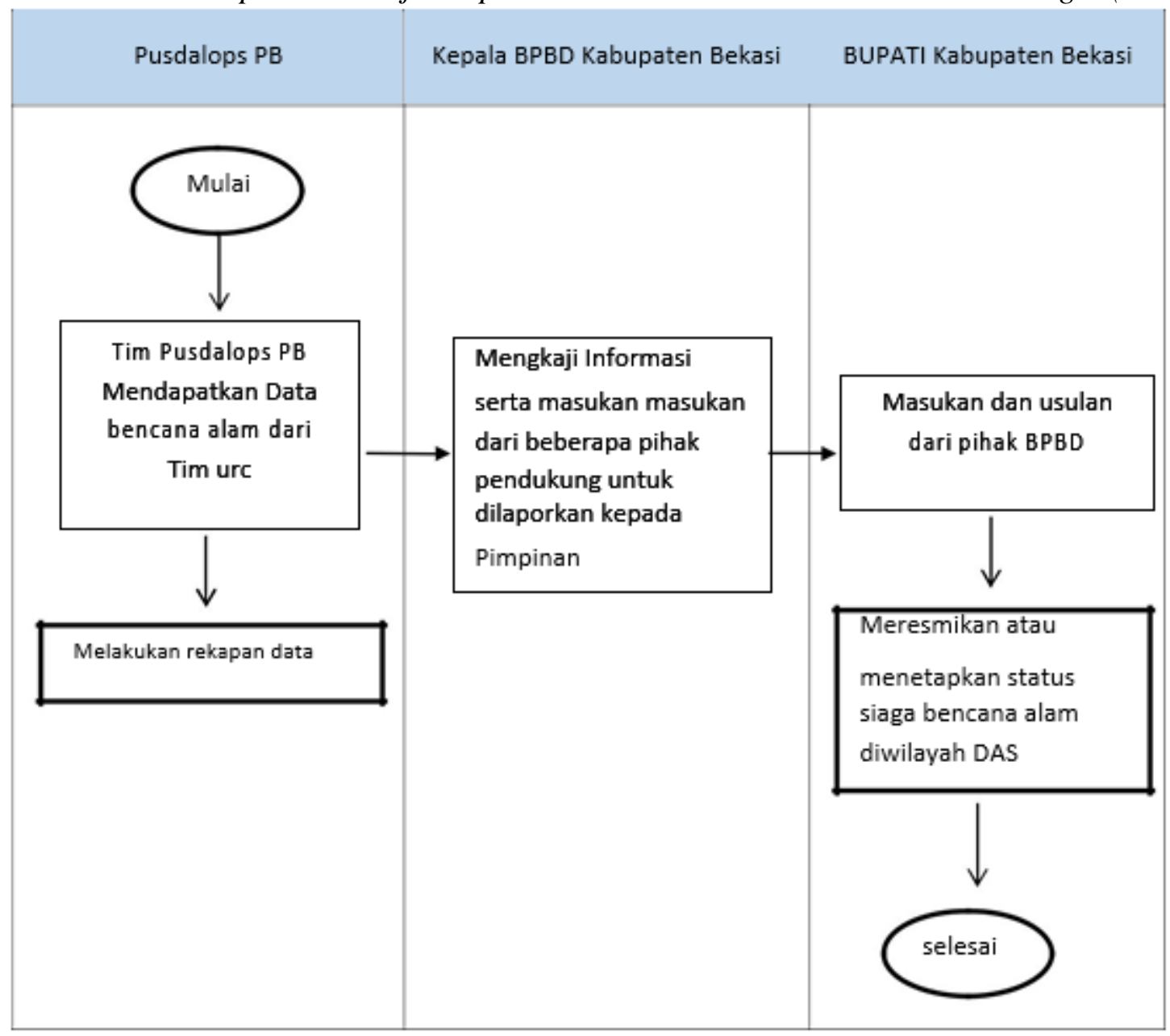

\section{Tampilan Antar Muka}

1. Rancangan Menu Utama

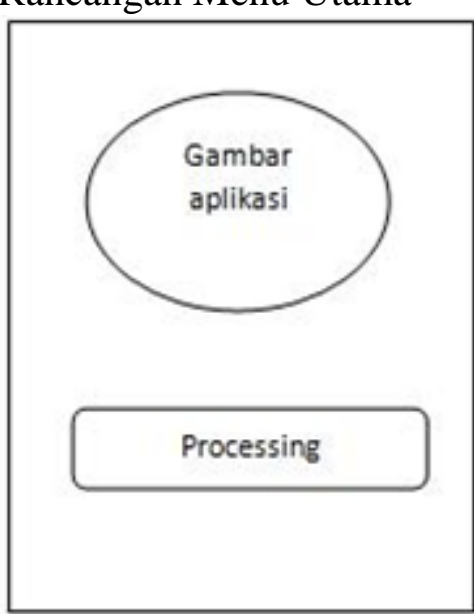

Figure 6.1 RancanganTampilan Aplikasi

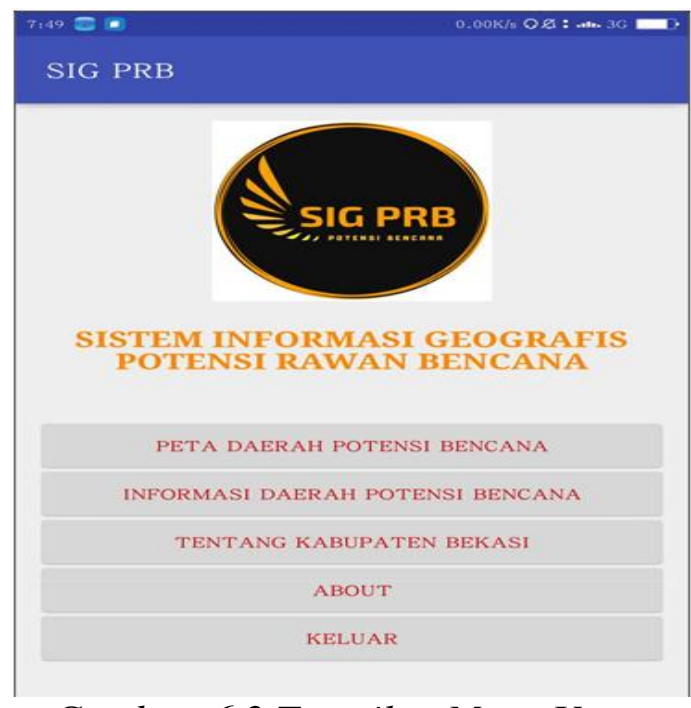

Gambar 6.2 Tampilan Menu Utama 


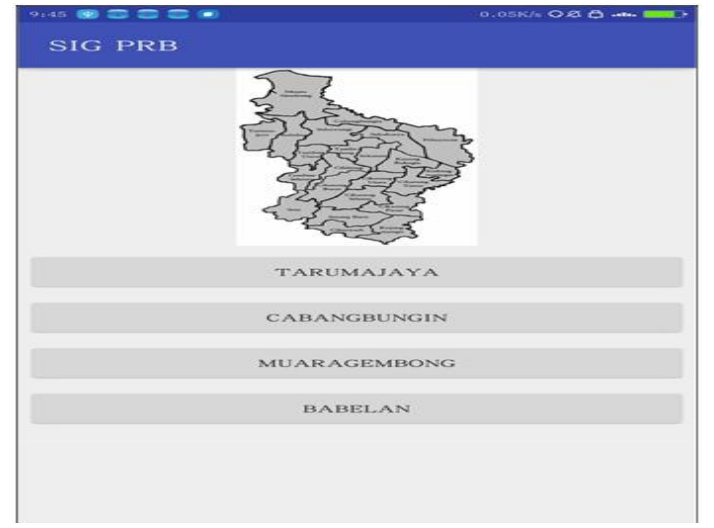

Gambar 6.3 Menu Maps

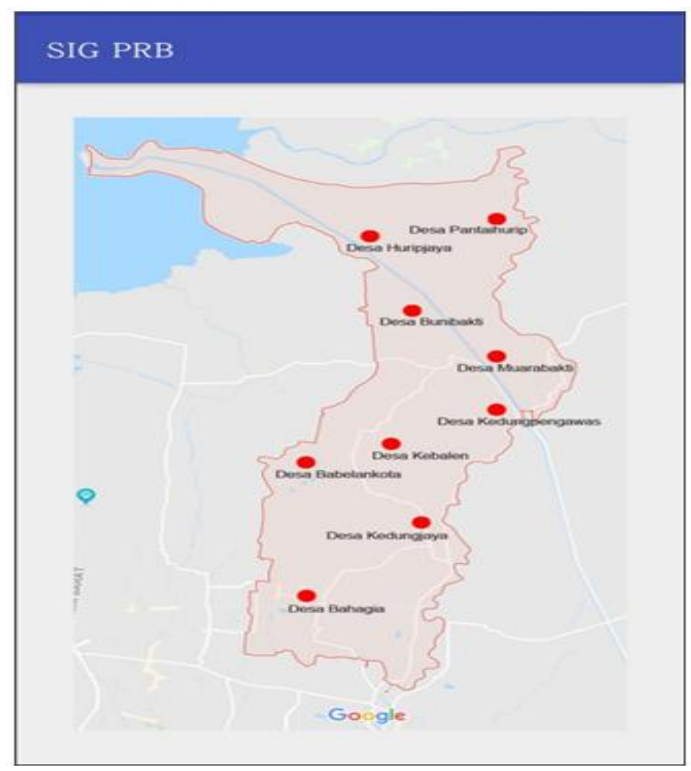

Gambar 6.4 Isi Peta Daerah Bencana

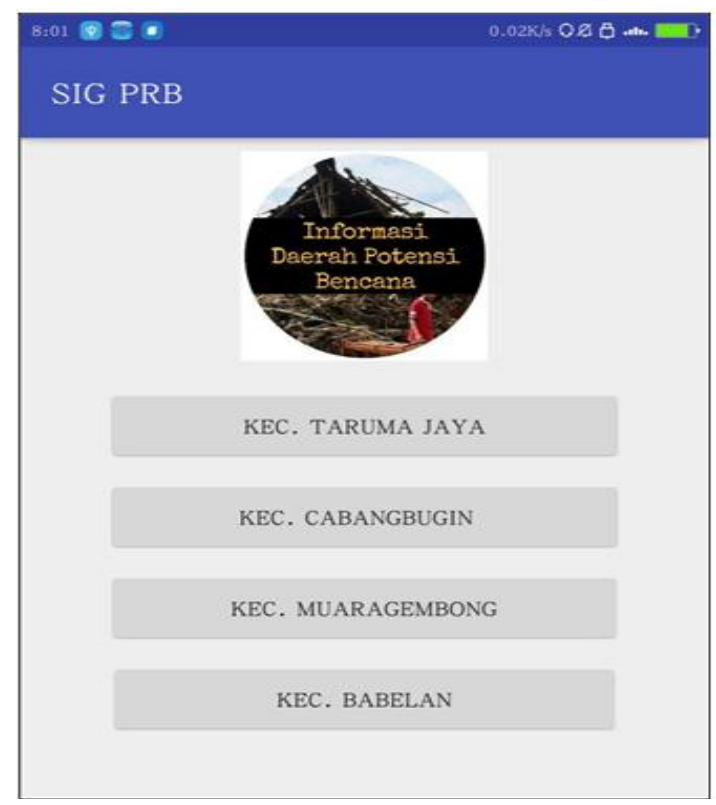

Gambar 6.5 Menu Informasi

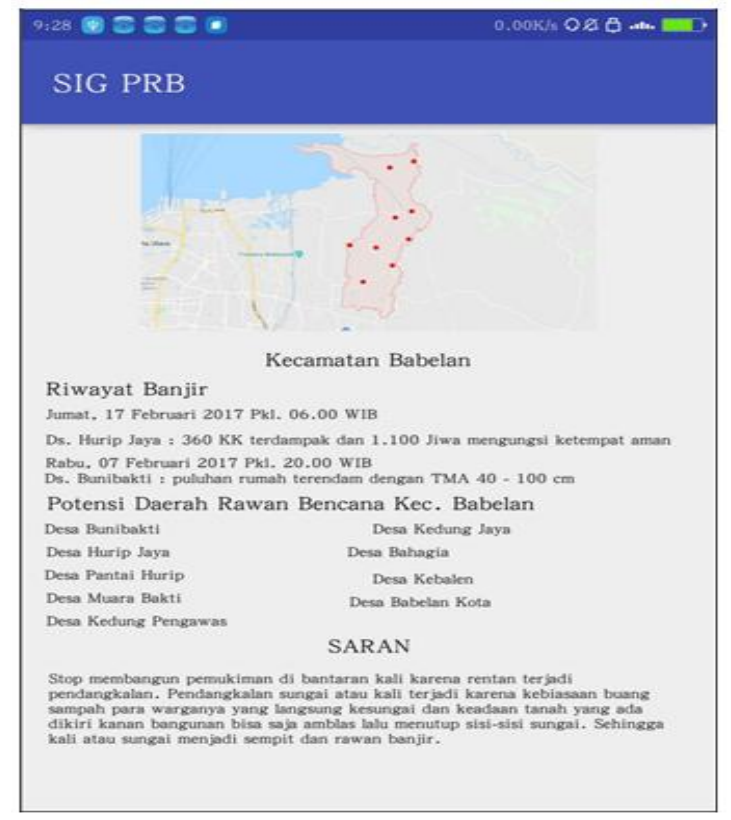

Gambar 6.6 Isi Menu Informasi

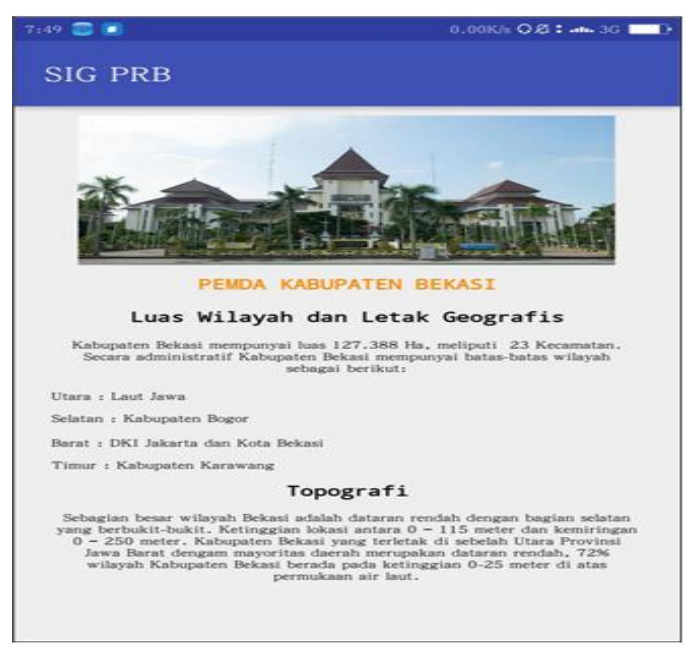

Gambar 6.7 Menu Kabupaten Bekasi

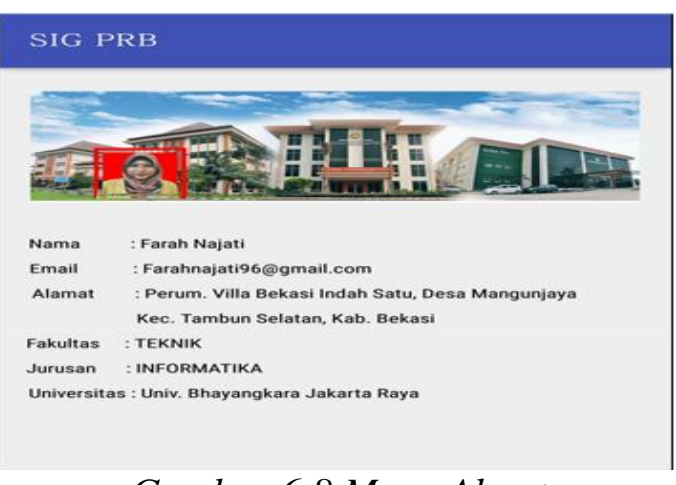

Gambar 6.8 Menu About 


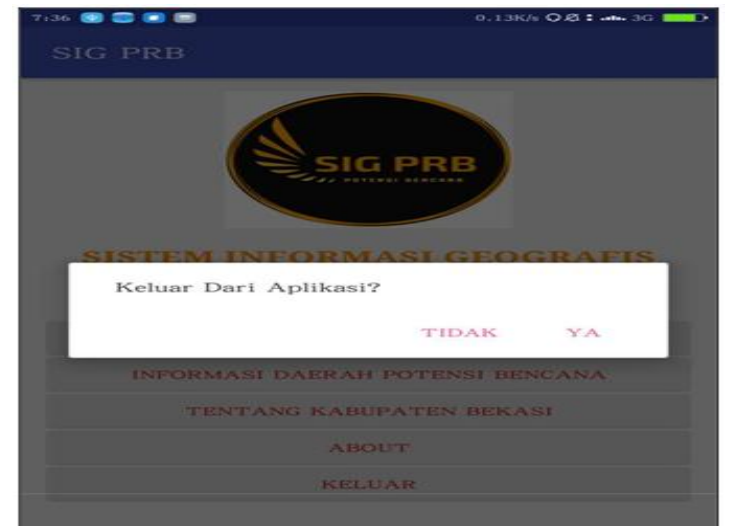

Gambar 6.9 Menu Keluar

\section{PENUTUP}

Berdasarkan penelitian yang sudah dilakukan mengenai perancangan sistem informasi geografis untuk pemetaan jenis potensi rawan bencana alam di wilayah daerah aliran sungai di Kabupaten Bekasi, maka dapat diambil beberapa kesimpulan sebagai berikut:

1. Bahwa informasi yang disampaikan dalam perancangan sistem informasi geografis untuk pemetaan jenis potensi rawan bencana alam di wilayah derah aliran sungai dikabupaten bekasi adalah informasi tentang titik titik tempat yang kemungkinan berpotensi bencana alam, Informasi dapat digunakan oleh masyarakat untuk mengetahui daerah yang berpotensi bencana alam di Kabupaten Bekasi,

2. Dengan adaya sistem informasi geografis pemetaan jenis potensi rawan bencana alam diwilayah daerah aliran sungai di Kabupaten Bekasi dapat membantu pemerintah dalam menyampaikan informasi kepada masyarakat tentang daerah yang berpotensi bencana alam agar tindakan pencegahan dan penanganan dapat dilakukan sesuai arahan dan petunjuk dari Badan Penanggulangan Bencana Daerah Kabupaten Bekasi.

\section{Daftar Pustaka}

Sukamto \& Shalahudidin, M. (2015). Rekayasa Perangkat Lunak Terstruktur dan Berorientasi Objek. Bandung: Informatika..

Julian Candra W dan M. Rajab F. (2017). Pengembangan Sistem Informasi Penjadwalan dan manajemen Keuangan Kegiatan Seminar dan Sidang Skripsi. Bandung: Informatika.

Rizki Hertia Maylindri. (2017). Rancang Bangun Sistem Informasi Geografis Penentuan Lokasi Potensi Sumber Daya Alam Dengan Metode Profile Matching:Informatika.

Ardiansyah, Kardono. (2017). Sistem Informasi Geografis (SIG) Pemetaan Jaringan Pipa dan Titik Properti Pelanggan di PT AETRA AIR Tangerang: Informatika.

Moh Agus Husaini, Wahyu Dwi P. (2017) Sistem Informasi Geografis Pemetaan Sekolah Berbasis Web di kecamatan Wonodadi Kabupaten Blitar.Blitar: Informatika

Theresia Devi Indriasari, Kusworo Anindito (2014). Analisa dan Perancangan Sistem Pengumpulan Data Bencana Alam: Informatika. 
Dani Raharjo, Warkim. (2015). Prototype Sistem Informasi Geografis Pasilitas Kesehatan di Kota Cirebon Berasis WEB. Jakarta: Informatika.

Agus Priyanto (2016). Perancangan Sistem Informasi Akademik Berbasis Blok Pada Fkik Kedokteran gigi unsoed Dengan Metode RAD (RapidApplication Development) Purwokerto: Informatika

Nadia F. (2017). Creat Your Andriod Applica tion.. Tegal: Informatika.

M. Nurhidayat. (2017). Jurus Rahasia Menguasai Android. Jakarta: Informatika.

Ir. Yuniar S. (2018). Koleksi Program Tugas Akhir dan Skripsi Dengan Android.

Tegal: Informatika. Deskripsi dan Tinjauan Kritis. Bandung: Penerbit Referens dan Nusa Media.

Safaat Nazrudin. (2012). Pemrograman Aplikasi Mobile Smartphone dan Tablet PC Berbasis Android. Bandung: Informatika

Tata, Sutabri. (2012). Analisis Sistem Informasi. Yogyakarta: Andi.

Tohari. (2014). Analisisi Serta Perancangan Sistem Informasi Melalui Pendekatan UML. Yogyakarta: Andi.

Wihardjo. (2012). Pembelajaran Berbantuan Komputer untuk Anak. PT Graha Ilmu: Yogyakarta.

Moyo Hady Purnomo ( 2016 ).PERANCANGAN MULTIMEDIA PEMBELAJARAN UNTUK TERAPI ANAK BERKEBUTUHAN KHUSUS, SMATIKA JURNAL ISSN $2087-0256$

Sri Setyaningsih ( 2016 ). APLIKASI PEMBELAJARAN ANAK BERKEBUTUHAN KHUSUS ( HIPERAKTIF ) ADHD BERBASIS ANDROID. JURNAL UNIVERSITAS PAKUAN 
